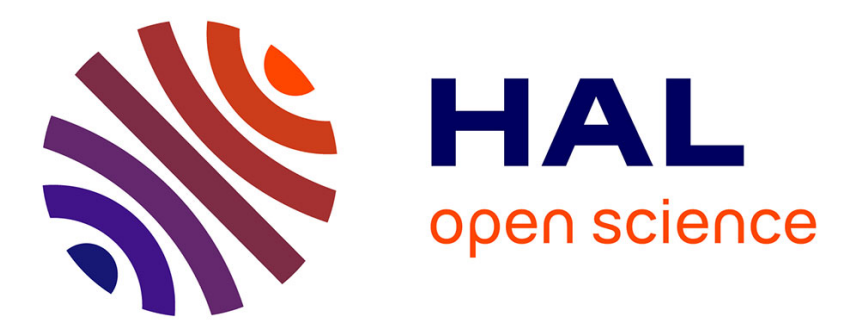

\title{
Amblydromalus limonicus (Acari: Phytoseiidae) as a biocontrol agent: literature review and new findings
}

M. Knapp, Y. van Houten, H. Hoogerbrugge, K. Bolckmans

\section{To cite this version:}

M. Knapp, Y. van Houten, H. Hoogerbrugge, K. Bolckmans. Amblydromalus limonicus (Acari: Phytoseiidae) as a biocontrol agent: literature review and new findings. Acarologia, 2013, 53 (2), pp.191-202. 10.1051/acarologia/20132088 . hal-01565998

\section{HAL Id: hal-01565998 \\ https://hal.science/hal-01565998}

Submitted on $20 \mathrm{Jul} 2017$

HAL is a multi-disciplinary open access archive for the deposit and dissemination of scientific research documents, whether they are published or not. The documents may come from teaching and research institutions in France or abroad, or from public or private research centers.
L'archive ouverte pluridisciplinaire HAL, est destinée au dépôt et à la diffusion de documents scientifiques de niveau recherche, publiés ou non, émanant des établissements d'enseignement et de recherche français ou étrangers, des laboratoires publics ou privés.

\section{(1) (1) $\$$}

Distributed under a Creative Commons Attribution - NonCommercial - NoDerivatives 44.0 


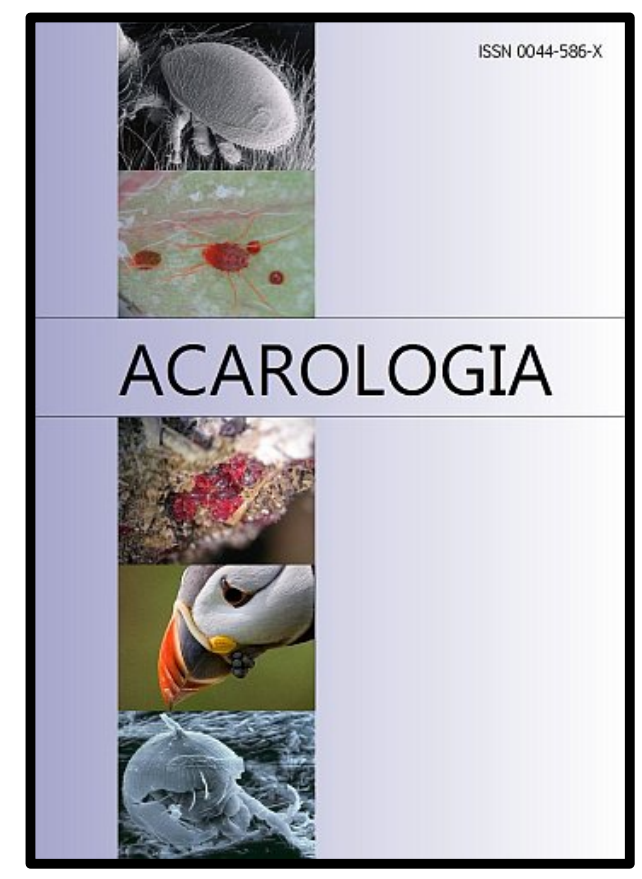

\section{ACAROLOGIA}

A quarterly journal of acarology, since 1959

Publishing on all aspects of the Acari

All information:

http://www1.montpellier.inra.fr/CBGP/acarologia/ acarologia@supagro.inra.fr

\section{OPEN ACCESS}

\section{Acarologia is proudly non-profit, with no page charges and free open access}

Please help us maintain this system by encouraging your institutes to subscribe to the print version of the journal and by sending us your high quality research on the Acari.

Subscriptions: Year 2017 (Volume 57): $380 €$ http://www1.montpellier.inra.fr/CBGP/acarologia/subscribe.php

Previous volumes (2010-2015): $250 € /$ year (4 issues)

Acarologia, CBGP, CS 30016, 34988 MONTFERRIER-sur-LEZ Cedex, France

The digitalization of Acarologia papers prior to 2000 was supported by Agropolis Fondation under the reference ID 1500-024 through the « Investissements d'avenir » programme

(Labex Agro: ANR-10-LABX-0001-01)
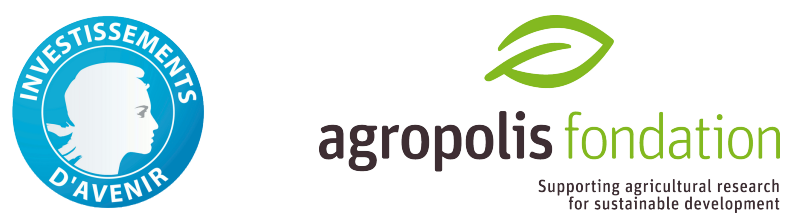

Acarologia is under free license and distributed under the terms of the

Creative Commons-BY-NC-ND which permits unrestricted non-commercial use, distribution, and reproduction in any medium, provided the original author and source are credited. 


\title{
AMBLYDROMALUS LIMONICUS (ACARI: PHYTOSEIIDAE) AS A BIOCONTROL AGENT: LITERATURE REVIEW AND NEW FINDINGS
}

\author{
Markus KnAPP, Yvonne van Houten, Hans HoOgerbrugGe and Karel BolCKMANS
}

(Received 06 September 2012; accepted 30 January 2013; published online 28 June 2013)

Koppert Biological Systems, P.O. Box 155, 2650 AD Berkel en Rodenrijs, the Netherlands.mknapp@koppert.nl, yvhouten@koppert.nl, hhoogerbrugge@koppert.nl, kbolckmans@koppert.nl.

\begin{abstract}
Amblydromalus limonicus (Acari: Phytoseiidae) was described in 1956 from citrus in California; its distribution range covers North and South America, Australia and New Zealand. It first caught the attention of biocontrol workers in the 1960s as natural enemy of the spider mites Oligonychus punicae and Tetranychus cinnabarinus in avocados and other fruit trees. In laboratory studies, A. limonicus developed into adults and laid eggs on several species of mites, thrips, whiteflies and scale insects, as well as on pollen. Interest into A. limonicus re-emerged in the early 1990s after the western flower thrips (WFT, Frankliniella occidentalis) had spread nearly all over the world. It was collected during surveys for WFT biocontrol agents in New Zealand and Australia. Laboratory and semi-field experiments in the Netherlands and Australia showed that $A$. limonicus was a very promising candidate for biological control of WFT in several greenhouse crops. However, it was not possible to establish a commercially viable mass rearing system. At around the same time A. limonicus was also identified in surveys in South America for classical biocontrol agents for the cassava green mite (Mononychellus tanajoa) in Africa. Detailed taxonomic research showed, however, that the mites collected in these surveys were a closely related, undescribed species that was given the name Amblydromalus manihoti in 1994. Recently, a mass production system for A. limonicus was developed and the mite became commercially available in January 2012. With the material from this mass production system, more semi-field and field trials could be conducted. Results showed that $A$. limonicus is also an excellent biocontrol agent for greenhouse whiteflies (Trialeurodes vaporariorum) in various greenhouse crops including roses, cucumbers and strawberries. As this predatory mite originates from more temperate areas, it is a good complement to Amblyseius swirskii, which is currently the most frequently used phytoseiid in thrips and whitefly control, and Transeius montdorensis, which also recently came on the market. Both species originate from sub-tropical regions and have a higher optimum temperature than $A$. limonicus.
\end{abstract}

KEYWORDS - biological control; predatory mites; greenhouse; whiteflies; thrips

\section{INTRODUCTION}

Generalist predatory mites of the family Phytoseiidae are important biocontrol agents for thrips and whiteflies in protected cultivation of vegetables and flowers (Sabelis and van Rijn, 1997; Nomikou et al., 2001). The major commercially available species are currently Neoseiulus cucumeris (Oudemans), Ambl- yseius swirskii (Athias-Henriot) and Transeius montdorensis (Schicha) (see e.g. Gerson and Weintraub, 2007); another species, Amblydromalus limonicus (Garman and McGregor) was put on the market recently. Although A. limonicus has been known to feed on several insect and mite species since the 1960s (McMurtry and Scriven, 1965; Swirski 
and Dorzia, 1968), research on its use as a biocontrol agent in greenhouse crops started only in the 1990s after the invasion of the western flower thrips, Frankliniella occidentalis (Pergande) into Europe (Van Houten et al., 1993; 1995a). Here, we review the taxonomy, distribution and biology of A. limonicus and present new results on its performance as a biocontrol agent of thrips and whiteflies in protected crops.

\section{LITERATURE REVIEW}

\section{Taxonomy and Distribution}

Amblydromalus limonicus was described as Amblyseius limonicus by Garman and McGregor (1956) from citrus trees in California. The following names and synonyms can be found in the literature: $T y$ phlodromus (Amblyseius) limonicus Chant; Amblyseius (Typhlodromalus) limonicus Muma; Typhlodromus limonicus Hirschmann; Amblyseius (Amblyseius) limonicus Wainstein; Typhlodromalus limonicus De Leon; Typhlodromalus garmani Chant and Typhlodromalus rapax (Moraes et al., 2004). According to Steiner and Goodwin (2005) and Minor (2008) A. limonicus is suspected to be the senior synonym of Amblydromalus lailae (Schicha), so far only reported from Australia.

Amblydromalus limonicus is distributed widely in temperate to subtropical regions of North, Central and South America, and also present in Hawaii, New Zealand (Moraes et al., 2004) and Australia (Steiner et al., 2003; Steiner and Goodwin 2005). The habitat range of $A$. limonicus is restricted to areas with moderate temperature and relatively high relative humidity. In California it is common on low-growing herbaceous plants as well as on trees and shrubs along the coast but it is not present in drier inland areas (McMurtry and Scriven, 1965; McMurtry et al., 1971).

During surveys for natural enemies of the cassava green mite, Mononychellus tanajoa (Bondar), morphologically similar phytoseiids were collected from tropical South America and initially called Amblyseius limonicus sensu lato (Braun et al., 1993; Moraes et al., 1994). However, collection records were almost exclusively from cassava. This fact, together with problems in rearing Amblyseius limonicus sensu lato with a method successfully used for Amblyseius limonicus sensu stricto as well as differences in the ability to survive and reproduce on pollen led to the separation of these species after detailed morphological examination and cross breeding experiments (Braun et al., 1993; Moraes et al., 1994). Amblyseius limonicus sensu lato was described as Amblyseius manihoti by Moraes et al. 1994 (now Amblydromalus manihoti according to Chant and McMurtry, 2005).

\section{Biology}

Amblydromalus limonicus is a generalist phytoseiid predatory mite and can feed and reproduce on whiteflies (Bemisia tabaci Gennadius and Trialeurodes vaporariorum Westwood), thrips (F. occidentalis, Thrips tabaci Lindeman and Retithrips syriacus Mayet), eggs of the moth Prays citri Milliere, and spider mites (e.g. Oligonychus punicae Hirst, Panonychus citri McGregor, Eutetranychus orientalis Klein and Tetranychus cinnabarinus Boisduval) (McMurtry and Scriven, 1965; Swirski and Dorzia, 1968; Van Houten et al., 1995a; Sengonca and Drescher, 2001; Van Houten et al., 2008).

However it is hindered by the large amount of webbing produced by some spider mite species (McMurtry and Scriven, 1965). It can develop and reproduce to a certain extent on armoured scale insect crawlers and has been observed to feed on citrus rust mite, Phyllocoptruta oleivora (Ashmead), although it did lay few eggs and did not complete immature development when fed exclusively on this prey (McMurtry and Scriven, 1965; Swirski and Dorzia, 1968). It also showed high oviposition rates when feeding on tomato russet mite, Aculops lycopersici (Massee) on tomato leaf discs but could not control the pest on intact tomato plants, probably because its movement and searching capacity was negatively affected by the glandular trichomes on leaves and stems of the plants (Park et al., 2010; Van Houten et al., 2010). On broad mite, Polyphagotarsonemus latus (Banks), immature survival and oviposition were very low (McMurtry et al., 1984a). Amblydromalus limonicus is a facultative predator and 
also feeds and reproduces on pollen of various plant species (McMurtry and Scriven, 1965; Swirski and Dorzia, 1968).

At $22.2^{\circ} \mathrm{C}$, adult females laid 2.3 eggs per day on P. citri as prey, 2.1 when fed with P. citri and Mesembryanthemum sp. pollen and 2.0 on Mesembryanthemum sp. pollen only. The oviposition with P. citri as prey was 0.1 eggs per day at $10.0^{\circ} \mathrm{C}$, increased to 2.7 at $26.7^{\circ} \mathrm{C}$, and thereafter decreased to 1.0 at $32.2^{\circ} \mathrm{C}$ (McMurtry and Scriven, 1965). Van Houten et al. (1995a) reported an oviposition rate of 3.2 eggs per day at $25{ }^{\circ} \mathrm{C}$ with first instar larvae of $F$. occidentalis as prey. The oviposition rates when feeding on $T$. vaporariorum on cucumber leaf discs at $25{ }^{\circ} \mathrm{C}$ were 3.7 eggs per day on young white eggs $(0-24 \mathrm{~h}$ old), 1.2 on brown eggs ( $>72 \mathrm{~h}$ old), 3.3 on crawlers and 3.4 on second and third instar nymphs (Van Houten et al., 2008). Swirski and Dorzia (1968) reported 1 egg per day with $B$. tabaci as prey but did not mention the whitefly stage used. With Tetranychus urticae (Koch) as prey on cucumber leaf discs $A$. limonicus laid 2.8 eggs per day when there was no webbing but only 0.4 when there was heavy webbing (Van Houten et al., 2008). Egg to adult development took about 6 days at $22.2{ }^{\circ} \mathrm{C}$ on citrus red mite as well as pollen, and the preoviposition period was 2.5 days (McMurtry and Scriven, 1965). The intrinsic rate of increase of an Australian population of A. limonicus (named Typhlodromalus lailae in the original publication (Steiner et al., 2003) but later re-identified as A. limonicus (Steiner and Goodwin, 2005)) at $25{ }^{\circ} \mathrm{C}$ on Typha sp. pollen was 0.38. Average oviposition over a 3-day period was $3.7 \mathrm{eggs}$ per day on Typha sp. pollen and 3.3 on first-instar Frankliniella schultzei Trybom larvae. Adult females consumed around 7 first instar thrips larvae per day (Steiner et al., 2003). With F. occidentalis as prey similar predation rates (6.9 first instar larvae per day) are reported (Van Houten et al., 1995a).

Eggs of A. limonicus are sensitive to low relative humidity. McMurtry and Scriven (1965) reported that only $50 \%$ of the eggs hatched at $60 \%$ relative humidity and no eggs at $50 \%$ or lower. The critical saturation deficits reported for $50 \%$ egg hatch at 25 ${ }^{\circ} \mathrm{C}$ range from $0.82 \mathrm{kPa}(74.1 \%$ r.h.) to $0.92 \mathrm{kPa}(71.1$ \% r.h.) (Bakker et al., 1993; Van Houten et al., 1995a;
Steiner et al., 2003).

\section{Use in biological control}

\section{Control of spider mites}

The first attempts to use A. limonicus as a biocontrol agent were made in California against the avocado brown mite, O. punicae. Although A. limonicus releases reduced the peak density of $O$. punicae on small avocado trees in a greenhouse by about $50 \%$ (McMurtry and Scriven, 1971), releases of $A$. limonicus on avocado trees in the field did not have any effect on $O$. punicae densities (McMurtry et al., 1984b). Amblydromalus limonicus had no control effect on P. citri on nursery citrus (Grafton-Cardwell et al., 1997). The authors attributed this to the high humidity requirements of $A$. limonicus and poor use of $P$. citri eggs by A. limonicus, as reported by McMurtry and Scriven (1965).

\section{Control of thrips}

The first evaluations of $A$. limonicus as biocontrol agent for $F$. occidentalis were conducted by Van Houten et al. (1993; 1995a). In laboratory experiments the predation and oviposition rate of $\mathrm{NeO}-$ seiulus barkeri Hughes, N. cucumeris, Iphiseius degenerans Berlese, Euseius hibisci (Chant), A. limonicus, Euseius scutalis (Athias-Henriot) and Euseius tularensis Congdon were compared on a diet of first instar F. occidentalis larvae. Amblydromalus limonicus had the highest predation rate with 6.9 larvae killed per day and the highest oviposition rate (3.2 eggs per day) of all species tested and also killed considerably more second instar thrips larvae than the other species. However, its eggs were the most sensitive to low relative humidity of all species tested. Therefore, it was concluded that I. degenerans and E. hibisci were the most promising candidates under the low humidity and short day conditions prevalent in Dutch greenhouses in the winter. Iphiseius degenerans and a non-diapausing strain of $N$. cucumeris (Van Houten et al., 1995b) were later mass-reared for thrips control. Mass rearing of E. hibisci never succeeded and I. degenerans lost its importance after the introduction of $A$. swirskii because the latter can be reared much more easily. 
Knapp M. et al.

TABLE 1: Predatory mite release strategies in the field experiment on whitefly and thrips control in cut roses with predatory mites

\begin{tabular}{llcc}
\hline & & \multicolumn{2}{c}{ Release rate (mobile mites per $\mathrm{m}^{2}$ per 2 weeks) } \\
Strategy & Phytoseiid species & Low pest pressure & High pest pressure \\
\hline 1 & A. limonicus & 100 & 200 \\
2 & A. swirskii & 100 & 200 \\
3 & T. montdorensis & 100 & 200 \\
4 & A. swirskii + A. limonicus & $50+10$ & $50+50$ \\
\hline
\end{tabular}

In several experiments it was demonstrated that A. limonicus is a better biocontrol agent for F. occidentalis on cucumber than other predatory mites. The thrips density on plants treated with $A$. limonicus remained near zero for 9 weeks after release whereas it increased to $130 \mathrm{~F}$. occidentalis per leaf on plants that were treated with N. cucumeris (Van Houten, 1996). In another experiment conducted by Messelink et al. (2006), the density of F. occidentalis larvae per 5 leaves 22 days after predatory mite release was significantly lower on plants where $A$. limonicus was released than on plants treated with $A$. swirskii, N. cucumeris or Euseius ovalis (Evans). Amblydromalus limonicus reached higher densities per leaf and reduced $F$. occidentalis populations on strawberries faster than $A$. swirskii in cage trials conducted in a greenhouse, although the number of cumulative thrips days accumulated during the experiments on leaves and flowers was not significantly lower than with A. swirskii (Hoogerbrugge et al., 2011a).

\section{Control of whiteflies}

Greenhouse whitefly, T. vaporariorum, populations on cucumber were reduced by $99 \%$ compared to the control by $A$. limonicus, $88 \%$ by $A$. swirskii and $76 \%$ by $E$. ovalis in experiments in small greenhouse compartments in the Netherlands (Pijnakker and Messelink, 2005). In cage trials with strawberries conducted in a greenhouse, both $A$. limonicus and $A$. swirskii releases resulted in a significantly better control of greenhouse whitefly compared to the untreated control and A. limonicus was significantly better than $A$. swirskii (Hoogerbrugge et al. 2011a). Amblydromalus limonicus is also an excellent biocontrol agent for T. vaporariorum in greenhouse roses. When $A$. swirskii, T. montdorensis and $A$. limonicus were released on whitefly infested roses, the number of cumulative whitefly days remained significantly lower on plants treated with A. limonicus than on plants treated with the other two phytoseiid species (Hoogerbrugge et al., 2011b).

\section{SEMI-FIELD AND FIELD EXPERIMENTS CONDUCTED AFTER ESTABLISHMENT OF THE MASS REARING SYSTEM}

\section{Materials and methods}

\section{Whitefly control in cucumber}

A semi-field experiment on whitefly control in cucumber was conducted in 12 screen cages (each 12 $\mathrm{m}^{2}, 2.5 \mathrm{~m}$ high) in a greenhouse at Koppert Biological Systems in Berkel en Rodenrijs, the Netherlands. Ten potted cucumber plants (cv. Greenfit) were placed in each cage in 2 rows of 5 plants each. The plants were watered and fertilized with a drip irrigation system. The trial was arranged in a completely randomized block design with 4 treatments ( 1 treatment/cage) and 3 replications per treatment. The treatments were (1) release of $25 \mathrm{~A}$. limonicus per plant, (2) release of 100 A. swirskii per plant, (3) release of 100 T. montdorensis per plant and (4) untreated control (no predatory mites released). As results of earlier laboratory and semi-field trials had indicated that $A$. limonicus can control whiteflies significantly better than the other species tested (see e.g. Hoogerbrugge et al., 2011b), this predatory mite was released at a lower rate. On 17 August 2011, when the plants had 10-11 leaves, 100 adult T. vaporariorum were released in each cage; this was repeated a week later. The predatory mites were released two days after the first whitefly release by distributing mixed mobile stages in sawdust over the plants. 
To evaluate the population development of pests and predatory mites 25 leaf disks $(7.5 \mathrm{~cm}$ diameter $)$ per cage were cut from young fully expanded $\mathrm{cu}-$ cumber leaves at weekly intervals for 7 weeks starting one week after the predatory mite releases. Immature whitefly stages and predatory mites (motile stages and eggs) were counted directly on the leaf disks with a stereo-microscope. Temperature and relative humidity in the cages were measured every 15 minutes with a data logger (HOBO H8, Onset, Pocasset, MA, USA). The mean temperature was $23.8^{\circ} \mathrm{C}$ (minimum $20.0^{\circ} \mathrm{C}$, maximum $35.0^{\circ} \mathrm{C}$ ) and the mean relative humidity was $61.3 \%$ (minimum $30.4 \%$, maximum $88.5 \%$ ). For statistical analysis a repeated measures ANOVA was performed on the densities of whiteflies and predatory mites after a $\log (x+0.5)$ transformation. Differences between treatments were tested at a $5 \%$ confidence level using Tukey's HSD test.

\section{Whitefly control in gerbera}

The experiment was conducted in 15 screen cages $(2.5 \times 0.9 \mathrm{~m})$ in a greenhouse at Koppert Biological Systems in Berkel en Rodenrijs, the Netherlands. Twelve potted gerbera plants (cv. Pixels) were placed in each cage. The plants were watered and fertilized with a drip irrigation system. The trial was arranged in a completely randomized block design with 5 treatments and 3 replications per treatment. The treatments were (1) A. limonicus (100 young egg-laying females and 30 males per cage), (2) A. limonicus (25 young egg-laying females and 10 males per cage), (3) A. swirskii (100 young egg-laying females and 30 males per cage), (4) T. montdorensis (100 young egg-laying females and 30 males per cage) and (5) untreated control (no predatory mites released). On 6 September 2011, 100 adult T. vaporariorum were released in each cage; this was repeated a week later. Two days after the first whitefly release, the predatory mites were released. For the release, the mites were sucked from the laboratory culture into pipette tips in a cold room $\left(8^{\circ} \mathrm{C}\right)$ and these tips were put on the plants in the cages. For each cage two tips were used. The gerbera plants were touching each other when the mites were released.
To evaluate the population development of pests and predatory mites 9 leaves per cage were picked 7 times at intervals of 7-10 days starting 5 days after the predatory mite releases. Immature whitefly stages and predatory mites (motile stages and eggs) were counted directly on the leaves with a stereo-microscope in the laboratory. Temperature and relative humidity in the cages were measured every 15 minutes with a data logger (HOBO H8, Onset, Pocasset, MA, USA). The mean temperature was $22.4{ }^{\circ} \mathrm{C}$ (minimum $18.7{ }^{\circ} \mathrm{C}$, maximum $34.7^{\circ} \mathrm{C}$ ) and the mean relative humidity was $66.4 \%$ (minimum $41.7 \%$, maximum $83.0 \%$ ). The population development of whiteflies and predatory mites was analysed with a repeated measures ANOVA as described above in the cucumber experiment.

\section{Whitefly and thrips control in roses}

The objective of this experiment was to compare the performance of $A$. limonicus, $A$. swirskii and T. montdorensis under commercial cut rose production conditions in the Netherlands. An area of $6480 \mathrm{~m}^{2}$ was selected in a commercial rose (cv. White Naomi) greenhouse and the experiment was laid out in a completely randomized block design with 4 treatments and 3 replications per treatment. The plot size was $540 \mathrm{~m}^{2}$ and the treatments are described in Table 1. Predatory mites were blown into the crop every 2 weeks with a handheld blower (MiniAirbug, Koppert Biological Systems). The number of phytoseiid mites released was determined in collaboration with the grower and varied according to pest pressure. From June to December 2011 the phytoseiids were released according to the strategy for low pest pressure; starting from January 2012, the high pest pressure release rates were used (Table 1). Whitefly and thrips populations were monitored with two yellow sticky traps $(25 \times 10 \mathrm{~cm})$ per plot, placed $10 \mathrm{~m}$ apart in the centre of each plot at the same height as the rose flowers. Insects on the traps were counted every 2 weeks and the trap replaced by a new one thereafter. Every two weeks 30 rose leaves were picked from each plot for predatory mite monitoring. These leaves were washed with hot water and soap over a fine sieve in the laboratory and the number of motile predatory mites 
was counted in the sieve with a stereo-microscope. No statistical analysis of the data was conducted.

Control of pests and diseases other than whiteflies and thrips was carried out by the rose grower using his standard pest management practices. In case treatments with synthetic pesticides were necessary they were conducted with products that were least toxic to the predatory mites. The rose plants were planted about 3 months before the experiment started in 2011. Before the trial started the grower had already released Phytoseiulus persimilis (Athias-Henriot) and Neoseiulus californicus (McGregor) against spider mites and $A$. swirskii in sachets against thrips and whiteflies.

\section{Results}

\section{Whitefly control in cucumber}

The density of whitefly immatures on the leaves remained low until about 5 weeks after the first release. Thereafter it increased quickly in the untreated control reaching about 450 per leaf disk at the last monitoring date. All three predatory mite species controlled the whiteflies well. At the end of the trial the density of the whiteflies was lowest in the $A$. limonicus treatment (11 per leaf disk), followed by $A$. swirskii (39 per disk leaf) and $T$. montdorensis (120 per leaf disk). There were significant differences $\left(F_{3,2366}=94.52, P<0.0001\right)$ in the development of the whitefly population between the treatments. The population remained significantly lower in all treatments receiving predatory mites than in the untreated control, and it was significantly lower in the $A$. limonicus and A. swirskii cages compared to T. montdorensis (Figure 1). Time significantly influenced the development of the whitefly population $\left(\mathrm{F}_{7,2366}=37.38\right.$, $P<0.0001)$ and there was a significant time $x$ treatment interaction $\left(F_{21,2366}=6.35, P<0.0001\right)$. The density of all phytoseiid species increased during the monitoring period (Figure 2). There were significant $\left(\mathrm{F}_{3,2366}=104.36, P<0.0001\right)$ differences in the development of predatory mite populations and a slight contamination of the untreated control at the end of the experiment (species not determined). Time significantly influenced the phytoseiid population development $\left(\mathrm{F}_{7,2366}=13.09, P<0.0001\right)$ and there was a significant time $x$ treatment interaction $\left(F_{21,2366}=3.05, P<0.0001\right)$. Despite the lower number of predatory mites initially released the population development of $A$. limonicus was equal to $A$. swirskii but better than T. montdorensis (Figure 2).

\section{Whitefly control in gerbera}

The whitefly population increased in all treatments. There were significant $\left(F_{4,778}=10.80, P<0.0001\right)$ differences between treatments and it remained lower than in the untreated control in all treatments with predatory mite release (Figure 3). Time significantly influenced the whitefly population development $\left(F_{5,778}=174.89, P<0.0001\right)$ and there was a significant time $x$ treatment interaction $\left(F_{20,778}=2.67\right.$, $P<0.0001)$. However, no whitefly control could be achieved in any of the predatory mite treatments. There was a slight contamination with predatory mites (species not determined) in the untreated control but the predatory mite population remained significantly $\left(\mathrm{F}_{4,778}=24.29, P<0.0001\right)$ lower there than in the predatory mite treatments. There were no differences in predatory mite population between the species and release rates tested $(\mathrm{P}>0.05)$. Time significantly influenced the development of the predatory mite population $\left(\mathrm{F}_{5,778}=20.52, P<0.0001\right)$ and there was a significant time $x$ treatment interaction $\left(\mathrm{F}_{20,778}=3.39\right.$, $P<0.0001)$. The phytoseiid density generally increased in the first 4-5 weeks after release and dropped down at the end of the trial. The variation in predatory mite densities per leaf was high and the drop was probably caused by the high whitefly densities on the leaves towards the end of the trial, which made the leaves sticky and unsuitable for the phytoseiids (Figure 4).

\section{Whitefly and thrips control in roses}

The number of whiteflies caught per sticky trap slowly increased from June to November and there were no differences between the treatments. In December there was a sharp increase in whitefly levels in all treatments except $A$. limonicus where the whitefly densities remained below 60 per trap per week throughout the experiment. After this increase the whitefly level remained high in the $A$. 
Schausberger, P. (ed.) Acari in a Changing World: Proceedings of the $7^{\text {th }}$ Symposium of EURAAC, Vienna, 2012

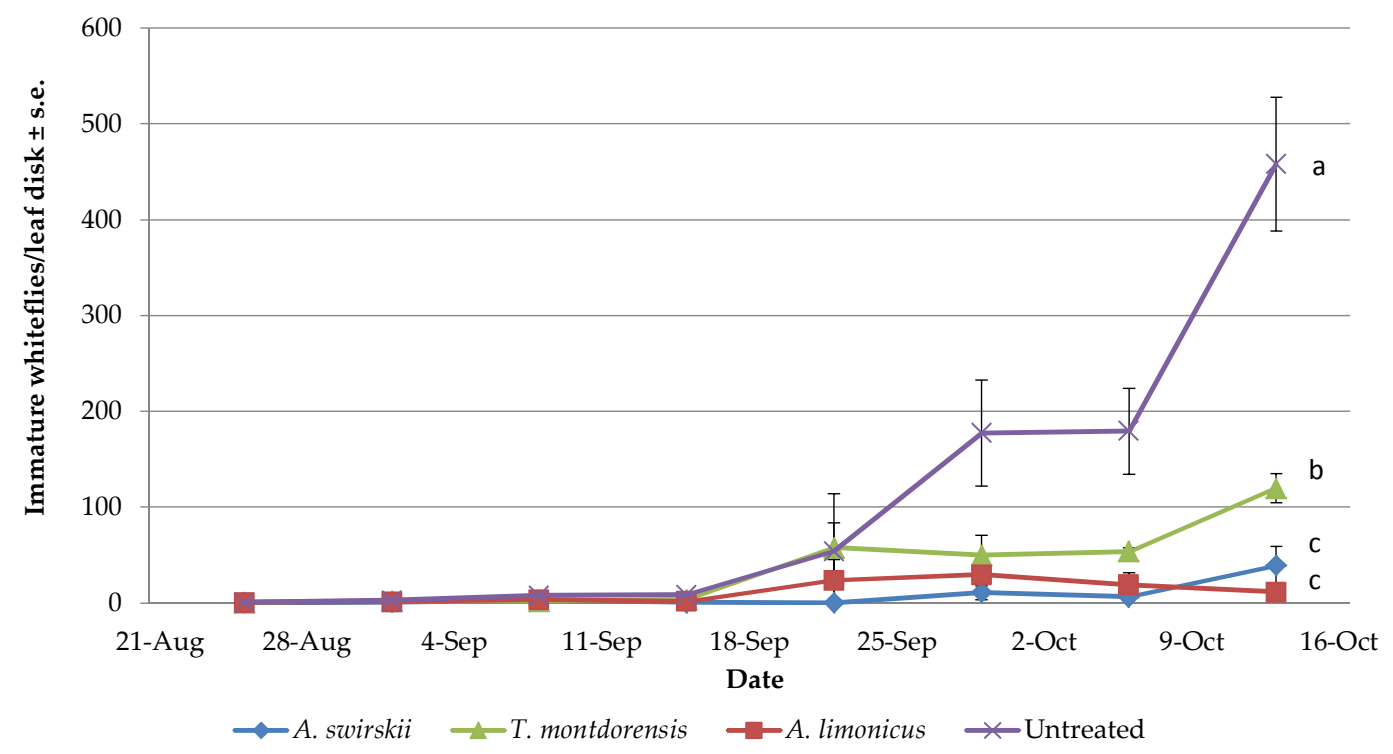

FIGURE 1: Development of the whitefly population on leaves in the cage trial on whitefly control in cucumbers with predatory mites. Shown are average densities of immature stages per leaf disk \pm s.e. Different letters indicate differences among treatments through time (Tukey-test, $P<0.05$ following repeated measures ANOVA)

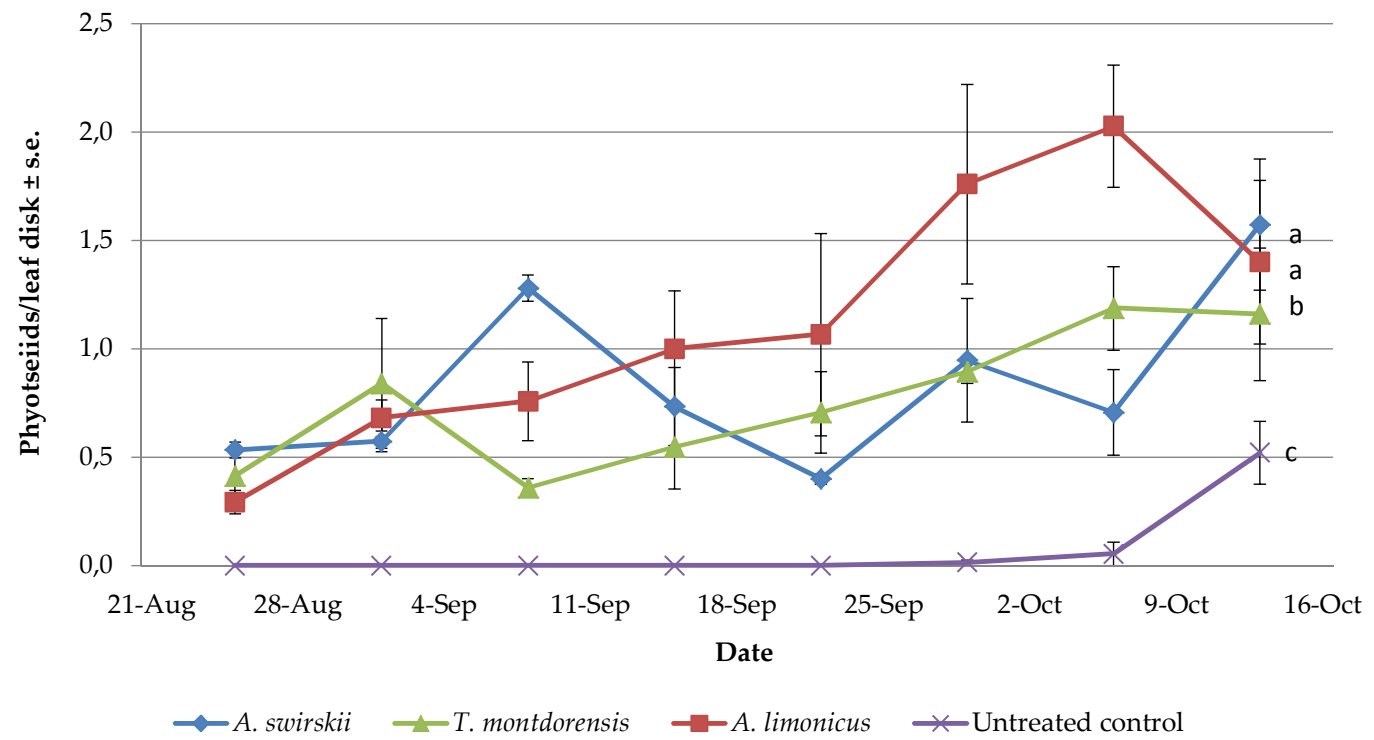

FIGURE 2: Development of the phytoseiid population on leaves in the cage trial on whitefly control in cucumbers with predatory mites. Shown are average densities of eggs and motile stages per leaf disk \pm s.e. Different letters indicate differences among treatments through time (Tukey-test, $P<0.05$ following repeated measures ANOVA) 


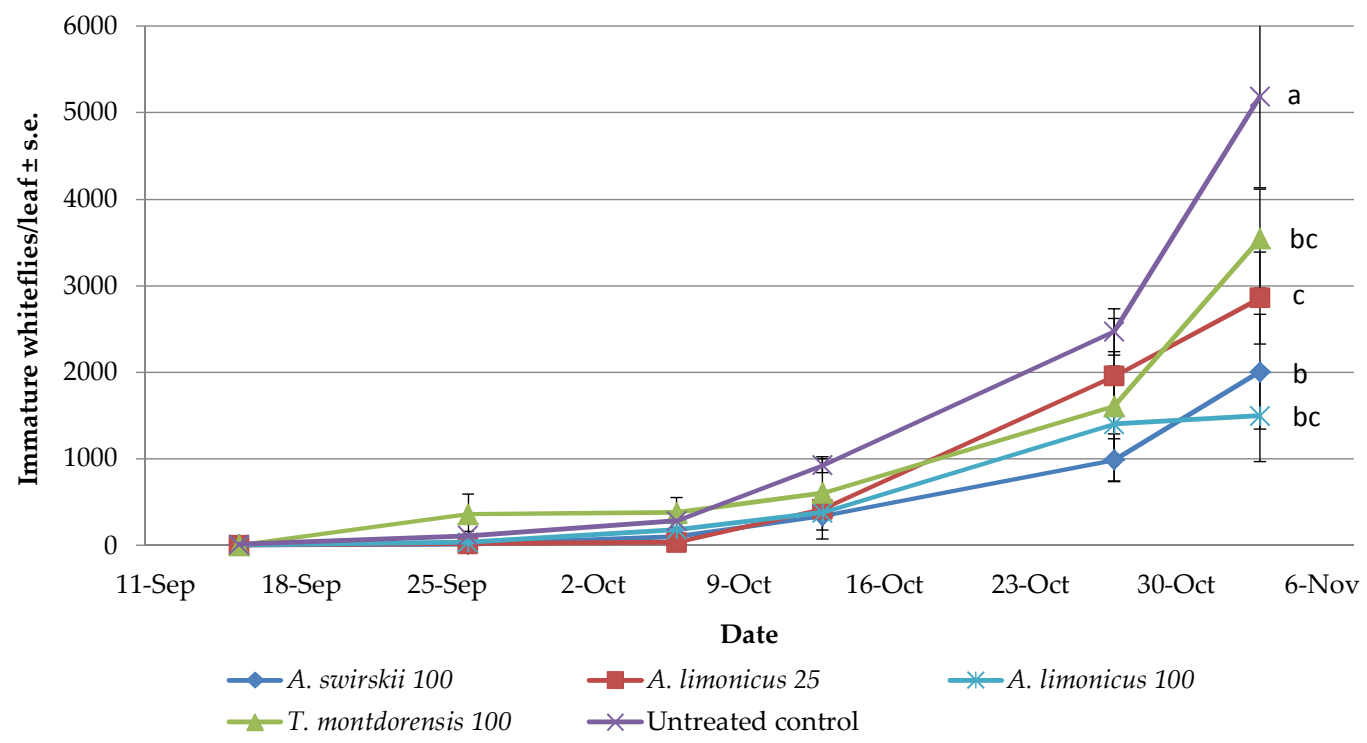

FIGURE 3: Development of the whitefly population on leaves in the cage trial on whitefly control in gerbera with predatory mites. Shown are average densities of immature stages per leaf \pm s.e. Different letters indicate differences among treatments through time (Tukey-test, $P<0.05$ following repeated measures ANOVA)

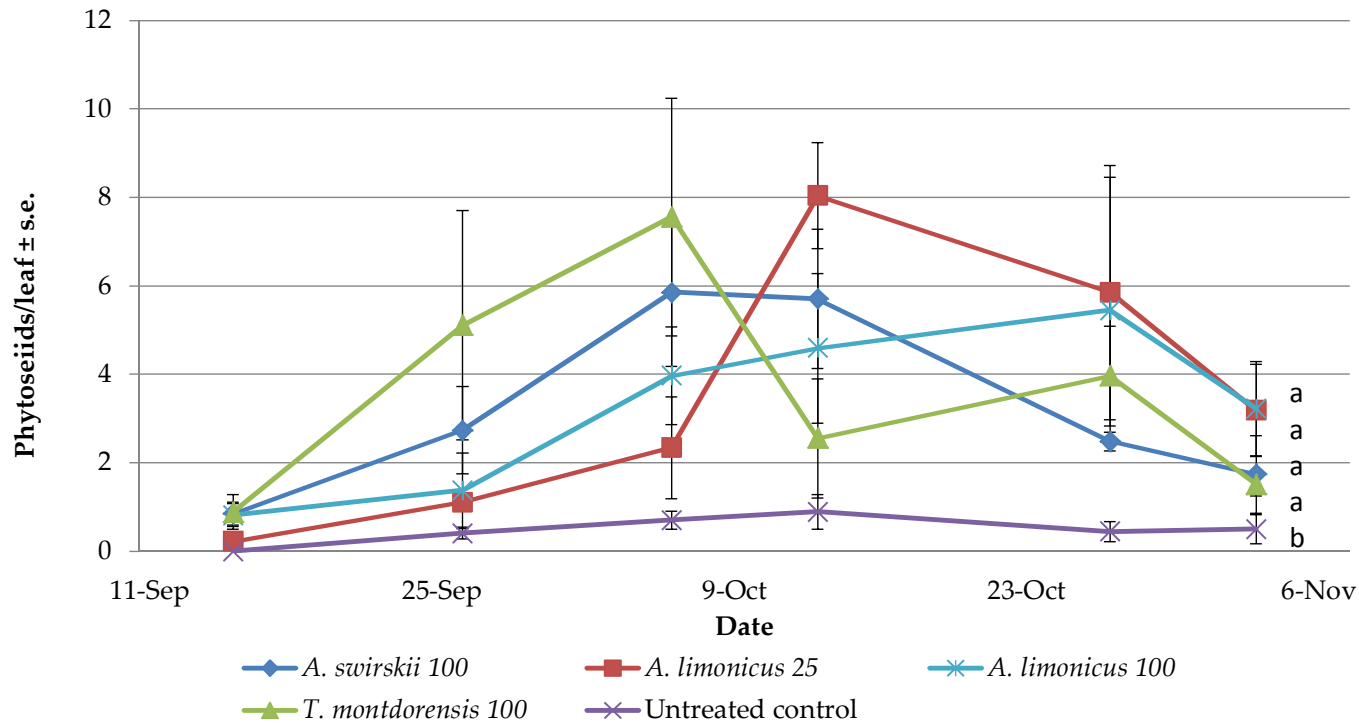

FIGURE 4: Development of the phytoseiid population on leaves in the cage trial on whitefly control in gerbera with predatory mites. Shown are average densities of eggs and motile stages per leaf \pm s.e. Different letters indicate differences among treatments through time (Tukey-test, $P<0.05$ following repeated measures ANOVA) 
Schausberger, P. (ed.) Acari in a Changing World: Proceedings of the $7^{\text {th }}$ Symposium of EURAAC, Vienna, 2012 Acarologia 53(2): 191-202 (2013)

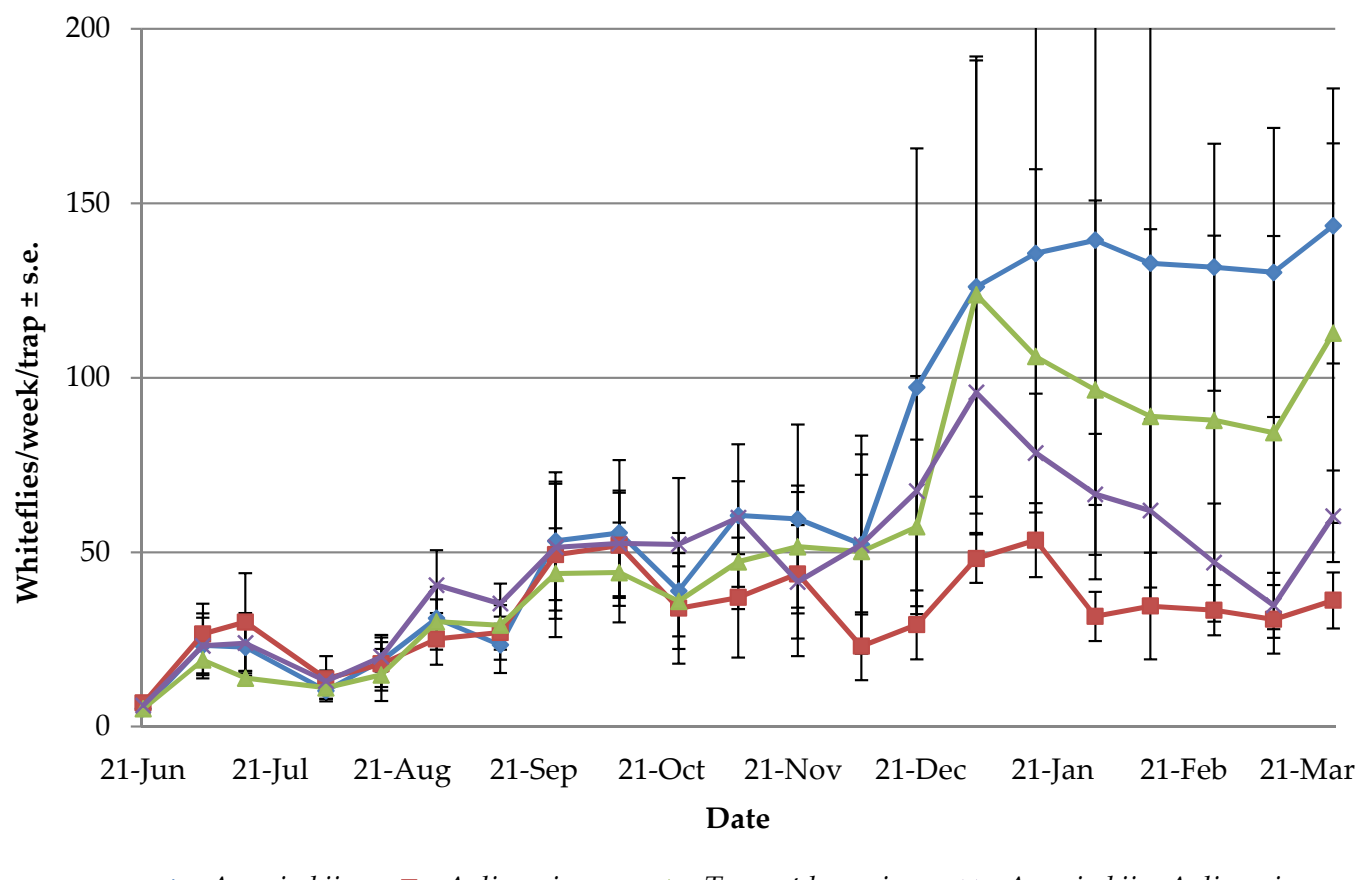

FIGURE 5: Development of the whitefly population on sticky traps in the field trial on whitefly and thrips control in roses with predatory mites. Shown are average densities of adults per sticky trap \pm s.e.

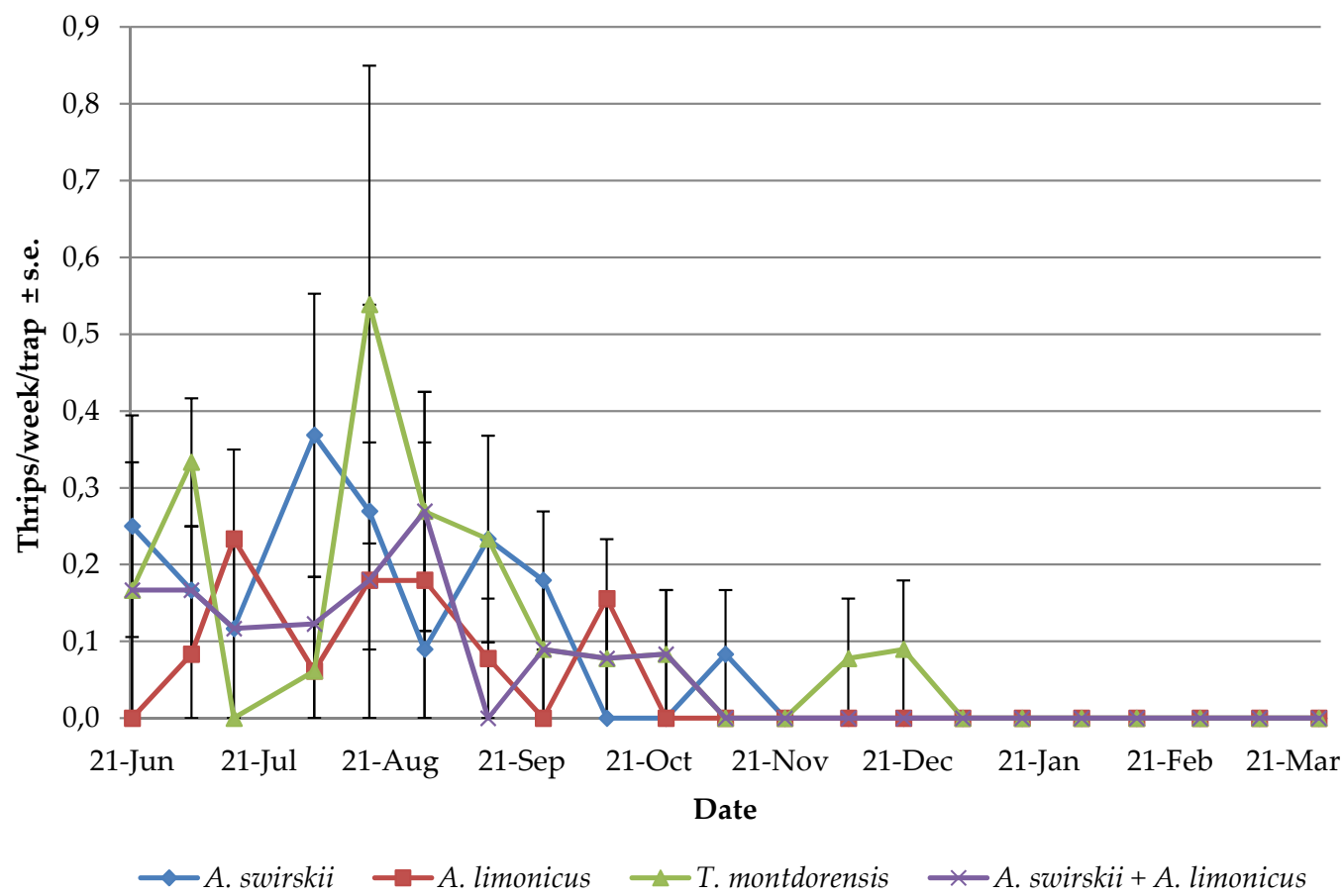

FIGURE 6: Development of the thrips population on sticky traps in the field trial on whitefly and thrips control in roses with predatory mites. Shown are average densities of adults per sticky trap \pm s.e. 


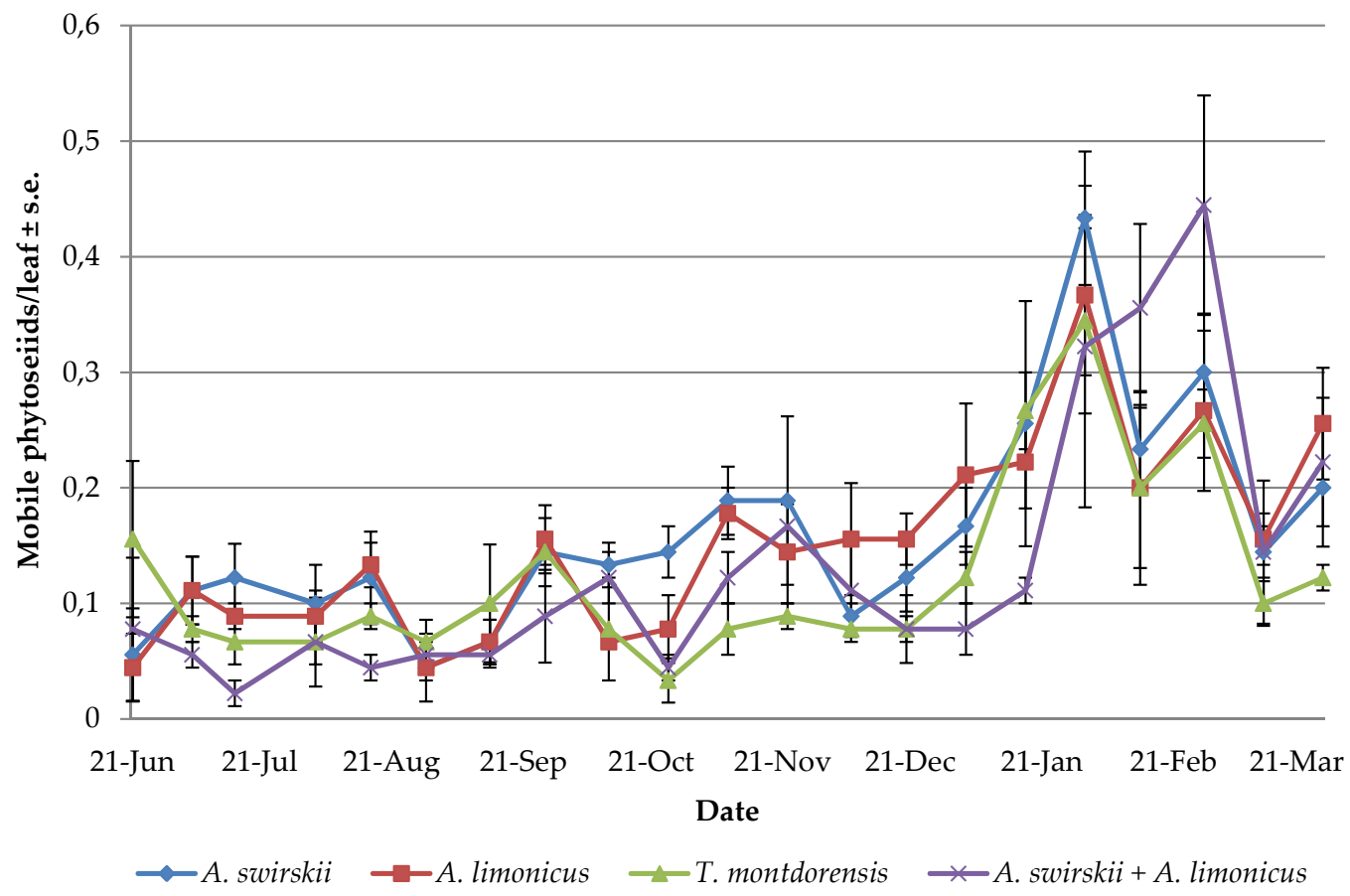

FIGURE 7: Development of the phytoseiid population on leaves in the field trial on whitefly and thrips control in roses with predatory mites. Shown are average densities of motile stages per leaf \pm s.e.

swirskii plots while it decreased again in the T. montdorensis and $A$. swirskii + A. limonicus treatments (Figure 5). The thrips densities on the traps remained low throughout and no thrips were caught any more in 2012. Due to the low tolerance for thrips the grower sprayed 3 times with spinosad and 2 times with lufenuron. There were no differences between the treatments (Figure 6). The predatory mite population on the leaves followed the whitefly development with a slight delay; no clear differences between the species were observed (Figure 7).

\section{DISCUSSION AND CONCLUSIONS}

Amblydromalus limonicus is a valuable addition to the currently available generalist predatory mite species for the control of thrips and whiteflies in protected crops. Although no detailed studies on the influence of temperature on demographic parameters have been published, preliminary tests at Koppert Biological Systems have shown that $A$. limonicus, which originates from more temperate regions than the Mediterranean species A. swirskii, remains active at lower temperatures than the latter. In a laboratory experiment, $87 \%$ of the A. limonicus eggs tested developed into adults at $13{ }^{\circ} \mathrm{C}$ in 22.5 days. Adult females laid 0.8 eggs per day while McMurtry and Scriven (1965) reported 0.1 eggs per day at $10^{\circ} \mathrm{C}$ on P. citri. In contrast, A. swirskii eggs do not hatch at $13{ }^{\circ} \mathrm{C}$ (Lee and Gillespie, 2011). On the other hand, A. swirskii performs better than $A$. limonicus at high temperatures. The daily oviposition of A. limonicus fed on Typha sp. pollen dropped from 3.0 at $25^{\circ} \mathrm{C}$ to 1.1 at $30{ }^{\circ} \mathrm{C}$ (Koppert, unpubl. data). On Mesembryanthemum sp. pollen, A. limonicus laid 2.7 eggs at $26.7^{\circ} \mathrm{C}$ and 1.1 at $32.2^{\circ} \mathrm{C}$ (McMurtry and Scriven, 1965). Lifetime fecundity of $A$. swirskii at $30^{\circ} \mathrm{C}$ was with 14.5 eggs per female only slightly lower than at $25^{\circ} \mathrm{C}$ (16.1 eggs per female) and the intrinsic rate of increase was greatest at 32 ${ }^{\circ} \mathrm{C}$ (Lee and Gillespie, 2011).

Semi-field experiments have shown that $A$. limonicus is superior to A. swirskii and T. montdoren- 
sis in whitefly control in roses under Dutch conditions (Hoogerbrugge et al. 2011b) and the results from the field tests presented here (Figure 5) indicate that similar results can be expected in commercial greenhouses. In cucumber, thrips control with A. limonicus was better than with the other phytoseiid species (Van Houten, 1996; Pijnakker and Messelink, 2005; Messelink et al., 2006). When released at a quarter of the release rate of $A$. swirskii and T. montdorensis, A. limonicus controlled greenhouse whiteflies equally well as $A$. swirskii and better than T. montdorensis (Figure 1). Promising results were also achieved against both pests in strawberries (Hoogerbrugge et al., 2011a), where the differences with $A$. swirskii under commercial glasshouse conditions might be bigger than shown in the cage experiments as temperatures in commercial conditions are lower than they were during the experiments. Whitefly control with predatory mites in gerbera remains to be difficult and could so far not be improved with $A$. limonicus. Since the introduction of A. limonicus in the market in 2012 a large number of Dutch cut rose producers has switched from regular releases of $A$. swirskii to A. limonicus.

\section{ACKNOWLEDGEMENTS}

We would like to thank the Dutch rose grower who made his greenhouse available for the field trial in roses.

\section{REFERENCES}

Bakker F.M., Klein M.E., Mesa N.C., Braun A.R. 1993 Saturation deficit tolerance spectra of phytophagous mites and their phytoseiid predators on cassava Exp. Appl. Acarol. 17: 97-113.

Braun A.R., Mesa N.C., Cuellar M.E., Melo E.L., Moraes G.J. 1993 - Biosystematics of phytoseiid mites (Acari: Phytoseiidae) associated with cassava - Exp. Appl. Acarol. 17: 205-213. doi:10.1007/BF00118437

Chant D.A., McMurtry J.A. 2005 - A review of the subfamily Amblyseiinae Muma (Acari: Phytoseiidae): Part VI: The tribe Euseiini n. tribe, subtribes Typhlodromalina n. subtribe, Euseiina n. subtribe, and Ricoseiina n. subtribe - Int. J. Acarol. 31: 187-224. doi:10.1080/01647950508684424

Garman P., McGregor E.A. 1956 - Four new predacious mites - Bull. South. Calif. Acad. Sci. 55: 7-13.
Gerson U., Weintraub P.G. 2007 - Mites for the control of pests in protected cultivation - Pest Manag. Sci 63: 658-676. doi:10.1002/ps.1380

Grafton-Cardwell E.E., Ouyang Y., Striggow R.A. 1997 Predaceous mites (Acari: Phytoseiidae) for control of spider mites (Acari: Tetranychidae) in nursery citrus — Environ. Entomol. 26: 121-130.

Hoogerbrugge H., van Houten Y., Knapp M., Bolckmans K. 2011a - Biological control of thrips and whiteflies on strawberries with Amblydromalus limonicus and Amblyseius swirskii - Bull. IOBC/WPRS 68: 65-69.

Hoogerbrugge H., van Houten Y., Knapp M., Bolckmans K. 2011b - Biological control of greenhouse whitefly on roses with phytoseiid mites - Bull. IOBC/WPRS 68: 59-63.

Lee H.-S., Gillespie D.R. 2011 —Life tables and development of Amblyseius swirskii (Acari: Phytoseiidae) at different temperatures - Exp. Appl. Acarol. 53: 1727. doi:10.1007/s10493-010-9385-5

McMurtry J.A., Scriven G.T. 1965 - Life-history studies of Amblyseius limonicus, with comparative observations on Amblyseius hibisci (Acarina: Phytoseiidae). Ann. Ent. Soc. America 58: 106-111.

McMurtry J.A., Scriven G.T. 1971 - Predation by Amblyseius limonicus on Oligonychus punicae (Acarina): effects of initial predator-prey ratios and prey distribution - Ann. Ent. Soc. Am. 64: 219-224.

McMurtry J.A., Oatman E.R., Fleschner C.A. 1971 — Phytoseiid mites on some tree and row crops and adjacent wild plants in southern California - J. Econ. Ent. 64: 405-408.

McMurtry J.A., Badii M.H., Johnson H.G. 1984a - The broad mite, Polyphagotarsonemus latus as a potential prey for phytoseiid mites in California - Entomophaga 29: 83-86.

McMurtry J.A., Johnson H.G., Badii M.H. 1984b - Experiments to determine effects of predator releases on populations of Oligonychus punicae. (Acarina: Tetranychidae) on avocado in California - Entomophaga 29: 11-19.

Messelink G.J., van Steenpaal S.E.F., Ramakers P.M.J. 2006 - Evaluation of phytoseiid predators for control of western flower thrips on greenhouse cucumber - BioControl 51: 753-768.

Minor M. 2008 - Phytoseiidae of New Zealand (http:/ / keys.lucidcentral.org/keys/v3/phytoseiidae/ key/Phytoseiidae/Media/Html/about.htm) Accessed 21 June 2012.

Moraes G.J., Mesa N.C., Braun A., Melo E.L. 1994 — Definition of the Amblyseius limonicus species group (Acari: Phytoseiidae), with descriptions of two new species and new records - Int. J. Acarol. 20: 209-217. doi:10.1080/01647959408684019 
Moraes G.J., McMurtry J.A., Denmark H.A., Campos C.B. 2004. - A revised catalog of the mite family Phytoseiidae - Zootaxa 434. pp. 494.

Nomikou M., Janssen A., Schraag R., Sabelis M.W. 2001 - Phytoseiid predators as potential biological control agents for Bemisia tabaci - Exp. Appl. Acarol. 25: 271291. doi:10.1023/A:1017976725685

Park H.H., Shipp, L., Buitenhuis R. 2010 - Predation, development, and oviposition by the predatory mite $\mathrm{Am}$ blyseius swirskii (Acari: Phytoseiidae) on tomato russet mite (Acari: Eriophyidae) - J. Econ. Ent. 103: 563569. doi:10.1603/EC09161

Pijnakker J., Messelink G. 2005 - Typhlodromips swirskii, un auxiliaire prometteur en culture de concombre PHM Rev. Hort. 471: 35-39.

Sabelis M.W., van Rijn P.C.J. 1997 - Predation by insects and mites - In: Lewis T. (Ed.) Thrips as crop pests. Wallingford: CAB International. p. 259-354.

Sengonca C., Drescher K. 2001 - Laboratory studies on the suitability of Thrips tabaci Lindeman (Thysanoptera, Thripidae) as prey for the development, longevity, reproduction and predation of four predatory mite species of the genus Amblyseius (Acari, Phytoseiidae) - J. Plant. Dis. Prot. 108: 66-76.

Steiner M.Y., Goodwin S., Wellham T.M., Barchia I.M., Spohr, L.J. 2003 - Biological studies of the Australian predatory mite Typhlodromalus lailae (Schicha) (Acari: Phytosiidae) - Austr. J. Ent. 42: 131-137. doi:10.1046/j.1440-6055.2003.00344.x

Steiner M.Y., Goodwin S. 2005 - Challenges for the implementation of integrated pest management of $\mathrm{cu}^{-}$ cumber pests in protected crops - an Australian perspective - Acta Hort. 731: 309-315.

Swirski E., Dorzia N. 1968 - Studies on the feeding, development and oviposition of the predaceous mite Amblyseius limonicus Garman and McGregor (Acarina: Phytoseiidae) on various kinds of food substances Israel J. Agric. Res. 18: 71-75.

Van Houten Y.M. 1996 - Biological control of western flower thrips on cucumber using the predatory mites Amblyseius cucumeris and A. limonicus - Bull. IOBC/WPRS 19(1): 59-62.

Van Houten Y.M., van Rijn P.C.J., Tanigoshi L.K., van Stratum P. 1993 - Potential of phytoseiid predators to control western flower thrips in greenhouse crops, in particular during the winter period - Bull. IOBC/WPRS 16(8): 98-101.

Van Houten Y.M., van Rijn P.C.J., Tanigoshi L.K., van Stratum P., Bruin J. 1995a - Preselection of predatory mites to improve year-round biological control of western flower thrips in greenhouse crops Ent. Exp. Appl. 74: 225-234. doi:10.1111/j.15707458.1995.tb01895.x

Van Houten Y.M., van Stratum P., Bruin J., Veerman A. $1995 \mathrm{~b}$ - Selection for non-diapause in Amblyseius cucumeris and Amblyseius barkeri and exploration of the effectiveness of selected strain for thrips control Ent. Exp. Appl. 77: 289-295. doi:10.1111/j.15707458.1995.tb02326.x

Van Houten Y.M., Rothe J., Bolckmans K.J.F. 2008 - The generalist predator Typhlodromalus limonicus (Acari: Phytoseiidae): a potential biological control agent of thrips and whiteflies - Bull. IOBC/WPRS 32: 237240 .

Van Houten Y.M., Hoogerbrugge H., Rothe J., Knapp, M., Bolckmans K.J.F. 2010 - Effects of Aculops lycopersici on trichome density and establishment of predatory mites (Acari: Phytoseiidae) on tomato - Abstracts, XIII Int. Congress of Acarology, Recife, Brazil. p. 283.

\section{COPYRIGHT}

$(\mathrm{cc}$ EY-No-ND Knapp M. et al. Acarologia is under free license. This open-access article is distributed under the terms of the Creative Commons-BY-NC-ND which permits unrestricted non-commercial use, distribution, and reproduction in any medium, provided the original author and source are credited. 